\title{
A Pilot Study on Developing Newsgames in Collaboration between Journalism and Computer Science Students
}

\author{
Marko Siitonen ${ }^{\mathrm{I}}$, Panu Uotila ${ }^{\mathrm{I}}$, Turo Uskali ${ }^{\mathrm{I}}$, \\ Jukka Varsaluoma ${ }^{\text {II }} \&$ Tanja VälisaloIII \\ I Department of Language and Communication Studies, University of Jyväskylä, Finland \\ II Department of Mathematical Information Technology, University of Jyväskylä, Finland \\ III Department of Music, Art and Culture Studies, University of Jyväskylä, Finland
}

\begin{abstract}
Producing digital and interactive journalistic products offers unique and important new learning opportunities for journalism education. This study analysed the experiences of two pilot courses on so-called 'newsgames' in a Finnish university in 2015 and 2017. The data consisted of the newsgames and other materials produced by the students, student feedback concerning the course and observations of teachers throughout the project. Our analysis demonstrates how producing newsgames in the context of higher education may foster project-based learning experiences, something that has been relatively rare in traditional journalism education. Collaboration with media companies also offered valuable feedback for the students throughout the course and provided them with an opportunity to practice selling their expertise. The study highlights how interdisciplinary and project-based cooperation may benefit journalism education.
\end{abstract}

Keywords: journalism education, journalism practice, newsgames, project-based learning, multidisciplinary

\section{Introduction}

Many journalists, educators and researchers have emphasised the need for journalism education to adapt quickly and even to innovate (Deuze, 2006; Lassila-Merisalo \& Uskali, 2011; Van Buskirk, 2010). Traditionally, however, journalism education in Europe has struggled to adopt the possibilities of new information and communication technology (ICT) into the curriculum (Servaes, 2009). Moreover, in the United States, in terms of data journalism education, only a little more than half of all journalism schools (59 out of 113) offered one or more data journalism course by the mid-2010s (Berrett \& Phillips, 2016). Similar concerns have been raised in relation to statistical reasoning

Siitonen, M., Uotila, P., Uskali, T., Varsaluoma, J. \& Välisalo, T. (2019). A pilot study on developing newsgames in collaboration between journalism and computer science students in Nordicom Review, 40(2): 143-155. doi:10.2478/nor-2019-0038. 
skills in journalism schools (Martin, 2017). New kinds of collaboration, for example with information technology (IT) specialists and interaction designers, are already required at the higher education level (Angus \& Doherty, 2015).

One avenue of innovation many news organisations have tried out is the use of 'game-like strategies that aim to approach and engage with the public through social media and playful approaches' (Ferrer Conill, 2018: 5). This interest can be understood partly alongside the continuing trend for 'news as entertainment' (Thussu, 2007), as well as being a result of the many opportunities for online interactivity that technological development and the changing media landscape have brought with them. Newsgames, or the 'broad body of work at the intersection of video games and journalism' (Bogost et al., 2010: 6), represent one manifestation of these strategies.

This paper contributes to the discussion surrounding the potential of newsgames in journalism education by presenting the results of a pilot course on newsgames, which was taught at the University of Jyväskylä, Finland, in the spring of 2015 and 2017. During the two courses, a total of 16 journalism and communication sciences students were put together with 12 computer science students to design and execute newsgames and related journalistic content in collaboration with a regional newspaper. While the course was certainly a novelty in Finland, we believe that it was also among the first of its kind internationally at a university level. In the section that follows, the theoretical background related to newsgames, as well as the pedagogical design of the course, are presented.

\section{Background}

There is a long history of news and games and what one may call playful journalism, going all the way back to crossword puzzles in American newspapers in the 1910s (Eliot, 1996). The term newsgames is much newer, however, first appearing in the 2000s (Bogost et al., 2010; Sicart, 2008). As with both journalism and (digital) games, there is not just one type of a newsgame, but rather a plethora of approaches that can fit under this concept. For example, Foxman (2014) distinguishes between contentdriven and situation-specific features in newsgames, while Bogost and colleagues (2010) recognise four distinct categories: 1) current event games, 2) infographics, 3) documentary games and 4) puzzles. For the purposes of the course described in this paper, we adopted Sicart's (2008: 28) definition of newsgames as 'serious computer games designed to illustrate a specific and concrete aspect of news by means of their procedural rhetoric, with the goal of participating in the public debate'. Sicart later adds that in practice, newsgames should be designed to relate to and accompany a specific piece of news.

The reasons behind developing newsgames are manifold. Some may relate to the idea that games offer a way to reach younger audiences, who are used to more interactive interfaces than traditional forms of journalism may provide. Others see promise in the way that games, sometimes conceptualised as 'playable systems', allow us to explore and understand complex systemic problems by experimenting with them (see for instance Rejeski et al., 2015). Looking at the state of games and play in modern newsrooms, Foxman (2014) concludes that 'it is difficult to ignore the powerful effect of digital content that playfully engages readers' and that 'games are present in most 
newsrooms, and a playful attitude seems beneficial in the production and distribution of digital content' (Foxman, 2014: 57-58). However, the debate on the potential of newsgames remains polarised, with impassioned voices who expect to revolutionise journalism and pessimistic voices who fear the trivialisation of society's problems (Plewe \& Fürsich, 2017).

Designing, let alone understanding, newsgames and the impact of gamification in the realm of journalism has proven to be challenging. The time needed to design and execute a newsgame may be difficult to assess (Ferrer Conill, 2018). It may also be difficult for readers to find a balance between the interpretative frames of games (as entertainment) and news (as trustworthy sources of information), leading into the possibility of seeing newsgames as banalizing journalism (Siitonen \& Launonen, 2014). Furthermore, newsgames are subject to some of the critique levelled against gamification as ideology and practice. Despite their lofty goals, gamified systems often result in what can only be called zombification, treating users as 'senseless mechanisms urged onwards by a desire for extrinsic rewards' (Conway, 2014: 129). Finally, we should acknowledge that gamification, and by extension also newsgames, are ideological, and not simply neutral tools with no meaning to themselves (Fuchs, 2014).

Despite the difficulties and criticism, fresh examples of newsgames continue appearing at a rate that suggests that their perceived benefits are greater than their perceived costs. It can be said that overall, newsgames are representative of the changing face of journalistic work in the 2000s, much like data journalism (Aitamurto et al., 2011; Appelgren \& Nygren, 2014; Coddington, 2015), drone journalism (Goldberg et al., 2013; Gynnild \& Uskali, 2018) and immersive/virtual reality journalism (Aronson-Rath et al., 2015; De La Peña et al., 2010). Using the affordances of contemporary information and communication technologies, these types of journalism typically require interdisciplinary collaboration to fully reach their potential, demanding that practitioners and educators alike challenge their existing modes of operation. However, learning to do this kind of collaboration cannot be taken for granted. Over the next paragraphs, we explore how instruction on creating newsgames may relate to journalism education at large.

An argument can be made that day-to-day journalism work is often focused on avoiding mistakes and, therefore, emphasising routines and stability over risk taking (Hesmondhalgh, 2019), whereas journalism education seems to be more open for experimentation and even failure. Deuze (2006) identifies two different positions for journalism education in society: the 'follower' mode and the 'innovator' mode. In the development of the newsgames pilot course analysed in this study, we side with Deuze (2006), who argues that journalism training should reflect the changing journalistic work culture, both in the industry and the development laboratory, and thus prepare students for innovation and change rather than a static future.

In addition to stressing innovation and experimentation, our course design emphasised the collaboration between various fields of expertise. Interdisciplinary education and research can provide the opportunity to fill the gaps left by the traditional disciplines, enabling the formation of a wider understanding of the world through the combination of two or more disciplines and inspiring technological and social innovations (Ellis, 2009). For example, in the context of newsgames, a task such as game design is something that neither journalism nor computer science students learn by default, nor is it something 
that either group can claim as their own. Instead, the team must work collaboratively, pooling resources and ideas and focusing on a joint goal in order to succeed. Interdisciplinarity can in turn be enhanced through collaborative teaching (Stefani, 2009) or co-teaching, a pedagogical approach that aims to help students take multiple perspectives on the topics being learned (Bacharach et al., 2008).

The newsgames course presented in this paper had students work in interdisciplinary project groups. The course included elements of problem-based learning, where students solved real-life problems and teachers facilitated the action rather than teaching in a traditional sense. However, the learning was distinguished from typical problem-based learning by the goal of creating a concrete artefact - an end product (Helle et al., 2006; Savin-Baden \& Major, 2004). In terms of journalism education, this kind of course offers opportunities for journalism students and instructors for testing new interactive forms of journalism in a safe, private or semi-public environment.

In the next section, we present the course outline and design, as well as a description and analysis of the outcomes of the course. The analysis highlights the possibilities and challenges related to teaching game design in the context of news production and adopting a multidisciplinary approach to project-based pedagogy. We see experiments such as the one presented here as a testbed for further discussion of the possibilities of mixing journalism and computer science students in order to present new themes in journalism in a more collaborative manner.

\section{The Newsgames Project: Course design and implementation}

The course Newsgames Project was designed and executed in a cooperative teaching initiative between the Department of Communication (in 2017, the Department of Language and Communication Studies) and the Department of Mathematical Information Technology at the University of Jyväskylä, Finland. The departments partnered with the regional newspaper Keskisuomalainen, which agreed to publish the finished newsgames if they reached their publication standards. Keskisuomalainen is the fourth largest daily newspaper in Finland, with a circulation of approximately 71,000 for the printed version and roughly twice that amount if one counts in the digital platforms.

Students were enrolled from both departments through a separate application process that included submitting a letter of motivation and an academic transcript. The first pilot project included nine journalism/communication students and six computer science students, while the second iteration of the course included seven journalism/ communication students and six computer science students. Participants were in their third or subsequent year of studies. Altogether, five teachers were involved in planning and executing the course. The journalism/communication students were awarded five credits for the course, which translates to 135 hours of study in the Finnish system. For the computer science students, the course was worth 10 credits in order to fit their degree structure and to allot sufficient programming resources. Upon completion of the course, the participants were expected to be able to 1) understand the principles of the design of newsgames, 2) apply previous knowledge and skills to the design and implementation of newsgames, 3) evaluate the importance of interactive and multimedia narration for journalism, 4) work as part of a multidisciplinary team and 5) plan and execute a multidisciplinary project. 
The course lasted for 15 weeks during the spring of 2015 and for 14 weeks during the spring of 2017. In both courses, the teachers divided the participants into three teams based on their interests and previous experience. Each team member was assigned a specific role (e.g., project manager, programmer, content producer and graphic designer) or a combination of two roles. The course began with lectures introducing the participants to the concept of newsgames and how it relates to current trends in journalism. The students were also introduced to the basics of journalism, game design, project work and project management. These lectures were divided among the participating teachers according to their expertise.

The participants began brainstorming ideas for possible newsgames immediately after the first meeting, during which the teams were introduced. Each team presented two or three game concepts to representatives from Keskisuomalainen, after which they chose one concept for development. The teams were given access to meeting rooms and working spaces. Each team had a designated teacher who acted as their coach during the development process. Game-testing sessions allowed for feedback from other teams and teachers.

The collaborating media house had certain requirements for the technical execution. For example, the games had to be web-based and able to work on mobile devices. Other than this, the project teams could choose their technological platform and their methods for completing the project. In the beginning, most groups designed simple software architecture and coding practices. Some groups also carried out prototyping using tools such as Unity and PowerPoint.

Each project group created their final game application with basic web technologies (HTML5 and JavaScript). They used a free open-source HTML5 game engine called 'Phaser', which is a mature up-to-date solution with support for modern web browsers and mobile devices. The programming language used in four of the projects was JavaScript, while in two cases, the students ended up using TypeScript, a superset of JavaScript, which was then compiled into JavaScript. The games fully ran on web browsers with no server-side components.

The participants of each course produced three newsgames for a total of six games (Table 1). The topics and styles of the projects varied significantly, ranging from looking at the dynamics of the 2015-2016 refugee crisis in Europe to explaining the complexities of running a microbrewery in Finland. All games were single-player games with mouse or touch controls. They had short-term play sessions similar to traditional arcade games or more modern web-based games. The style and mechanics of the games varied as well, including reaction puzzles and simple 'select one of two options' games with a mostly linear progression. The games produced during the first pilot course leaned more into the direction of simulating complex systems, while the games produced during the second pilot course took a more narrative approach to game design. In addition, all games in 2015 were real-time games, whereas the games in 2017 were turn-based. To make the outcomes of the course clearer, we present two of the games - The Operation Center and Before, everything was... - in more detail. 
Table 1. Outline of newsgames produced during the two pilot courses

\begin{tabular}{|c|c|c|c|c|}
\hline Name (in Finnish) & Topic & Key mechanics & Year & $\begin{array}{l}\text { Number of } \\
\text { players }\end{array}$ \\
\hline $\begin{array}{l}\text { Microbrewery } \\
\text { (Pienpanimo) }\end{array}$ & $\begin{array}{l}\text { Establishing and run- } \\
\text { ning a microbrewery } \\
\text { in Finland }\end{array}$ & $\begin{array}{l}\text { Resource manage- } \\
\text { ment, "simulation"? }\end{array}$ & 2015 & $\begin{array}{l}2,050 \text { (until } \\
\text { August } \\
\text { 2016) }\end{array}$ \\
\hline $\begin{array}{l}\text { The Operation Center } \\
\text { (Tilannekeskus) }\end{array}$ & $\begin{array}{l}\text { Decision-making in } \\
\text { the police operation } \\
\text { center }\end{array}$ & $\begin{array}{l}\text { Real time puzzle, } \\
\text { resource manage- } \\
\text { ment, "simulation"? }\end{array}$ & 2015 & $\begin{array}{l}5,689 \text { (until } \\
\text { August } \\
\text { 2016) }\end{array}$ \\
\hline $\begin{array}{l}\text { Save Refugees from } \\
\text { Syria } \\
\text { (Pelasta Syyrian pako- } \\
\text { laiset) }\end{array}$ & $\begin{array}{l}\text { Distributing the } \\
\text { asylum seekers from } \\
\text { Syria to European } \\
\text { countries }\end{array}$ & Management & 2015 & $\begin{array}{l}490 \text { (until } \\
\text { August } \\
2016 \text { ) }\end{array}$ \\
\hline $\begin{array}{l}\text { Before, everything } \\
\text { was... } \\
\text { (Ennen oli kaikki...) }\end{array}$ & $\begin{array}{l}\text { Living through the life } \\
\text { of a person born in } \\
\text { Finland in } 1917\end{array}$ & $\begin{array}{l}\text { Story-focused, } \\
\text { interactive story, } \\
\text { multiple-choice, } \\
\text { random elements, "life } \\
\text { simulator" }\end{array}$ & 2017 & \\
\hline $\begin{array}{l}\text { Doctor shortage } \\
\text { (Lääkäripula) }\end{array}$ & $\begin{array}{l}\text { Working for } 1 \text { week as } \\
\text { a general paediatrician }\end{array}$ & $\begin{array}{l}\text { Story, little resource } \\
\text { management, multiple } \\
\text { choice, random } \\
\text { elements }\end{array}$ & 2017 & \\
\hline $\begin{array}{l}\text { Cybercrime } \\
\text { (Kyberrikollisuus) }\end{array}$ & $\begin{array}{l}\text { Choosing and execu- } \\
\text { ting cyber-attacks }\end{array}$ & "Simulation" & 2017 & \\
\hline
\end{tabular}

\section{The Operation Center}

The design of The Operation Center was based on real-life events taken from actual police reports. The game illustrates how long distances and a relatively small number of patrols slow down the work of the police, as well as the kinds of decision making that goes on behind the scenes before a patrol car arrives at the location of a suspected crime.

Figure 1 depicts the graphical user interface of the game. The image on the left side shows the title screen, with buttons for playing the game ('Pelaa') and for receiving further instructions ('Ohjeet'). The rightmost image shows the user interface presented during gameplay, which was modelled loosely on the actual systems used in police operation centers in Finland.

In the game, the player is presented with a stylised map of a city. On this map, symbols for emergency calls appear, and the player has to allocate their resources (in the form of police patrols) to take care of the ever-growing number of cases in need of attention. Since it takes time for the police patrols to navigate from one end of the map to the other, the players have to be mindful of where their patrols are at any given point in time, as well as which areas might require a patrol even if there is no immediate need for them. The game has three levels and gets progressively harder over time. One playthrough takes approximately 7 minutes, but due to the increasing difficulty designed into the game, it is highly likely that the player will experience a 'game over' before completing the game.

The game was embedded within a newspaper article looking into the data behind police operation centers in Finland. The article detailed the lack of local police resources and the most typical police operations and crimes in Central Finland. 
A Pilot Study on Developing Newsgames in Collaboration between Journalism and Computer Science Students

Figure 1. Title screen and user interface of The Operation Center

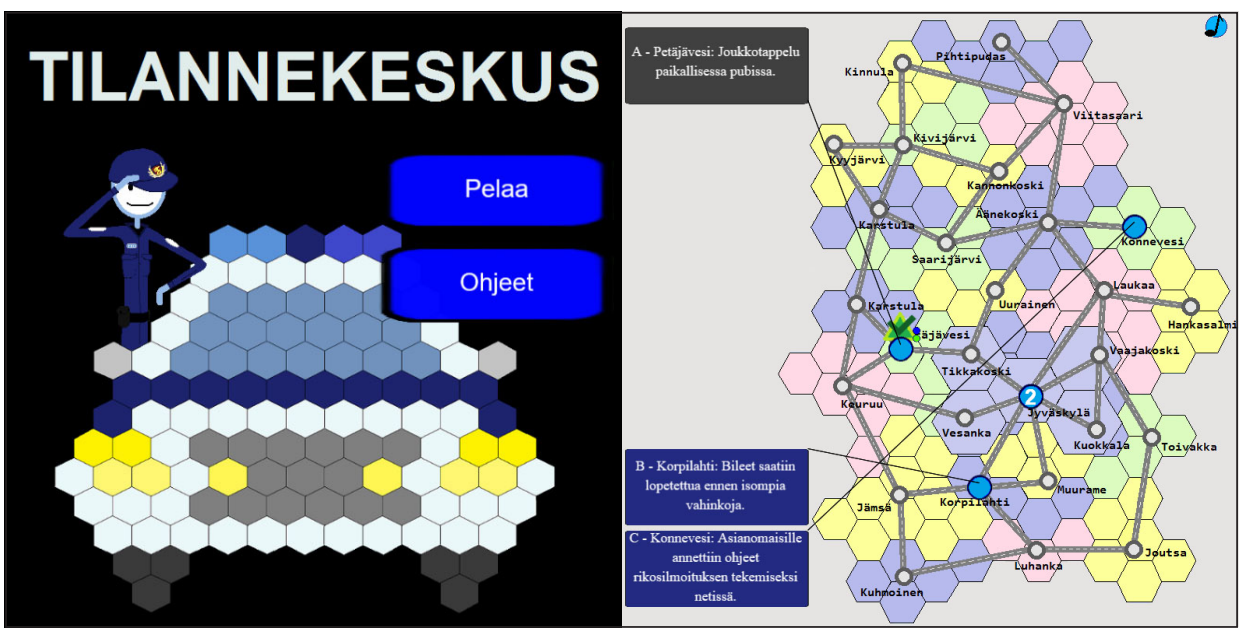

Comments: The Finnish words on the title screen (left image) mean 'play' (pelaa) and 'instructions' (ohjeet). The user interface (right image) was modelled on systems used in Finnish operation centers.

Before, everything was...

This game used archive photos and statistics to create different life stories and provided multiple choice questions for the player to influence the game's story. Figure 2 depicts the title screen of the game, with the option of choosing ('Valitse') to play as a male or a female character.

Figure 2. Title screen of Before, everything was ...

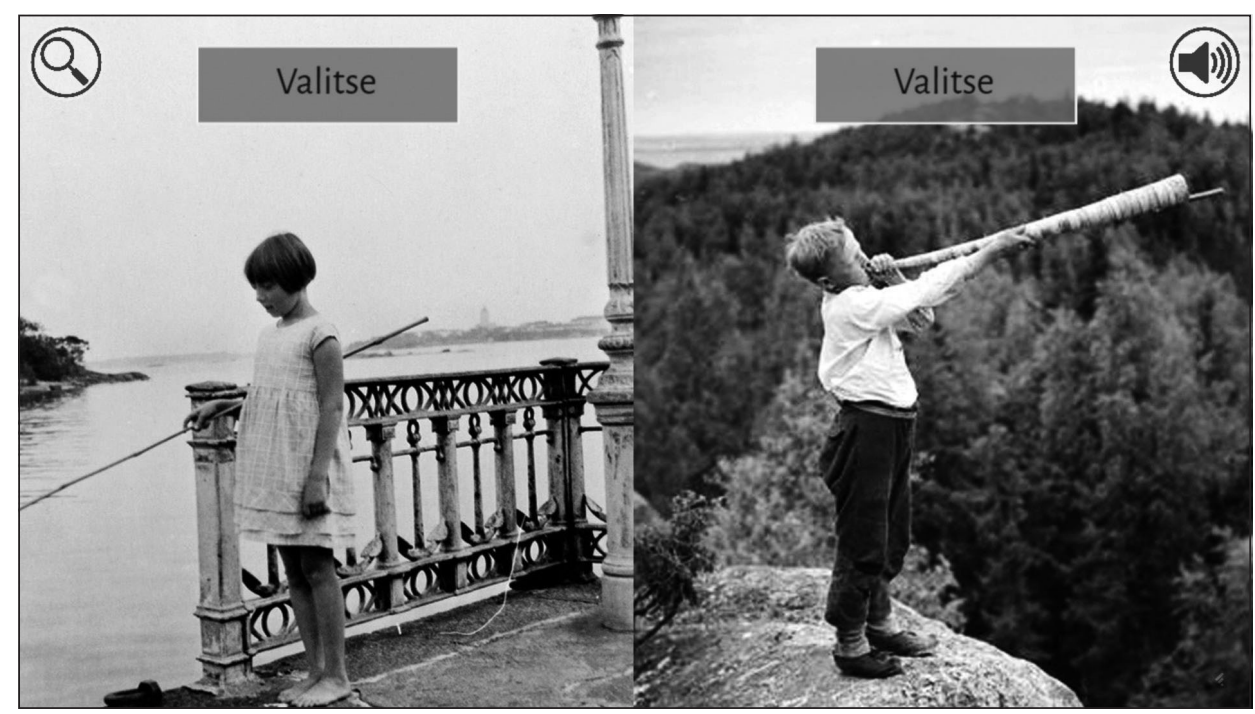

Comments: The left photograph was obtained from the archive of the Helsinki City Museum (photographer unknown). ${ }^{1}$ The right photograph was obtained from the Finnish Heritage Agency (photographer: Heinrich Iffland). ${ }^{2}$ Both photographs were downloaded from www.finna.fi, a site that provides free access to material from Finnish museums, libraries and archives. 
The design of the game Before, everything was ... highlights the experience of an individual in history. One playthrough is relatively short, lasting only a few minutes. This is due to the fact that sometimes, the story ends almost as soon as the player's character is born. The main idea behind this design choice was to explore several 'lives' with multiple playthroughs of the game. Mechanically, the game emphasises the randomness of life and how meaningful certain choices may (or may not) be. The final result can be characterised as an interactive story that has its roots in historical facts and statistics. The player's choices are limited to selecting from a few alternatives offered to them at certain intervals in the story of the game.

The game uses photographs in its graphical presentation, and the graphics consist mostly of actual historical photos from several museums and archives, including the Museum of Central Finland, the Finnish National Gallery, the Helsinki City Museum, the Finnish Heritage Agency, the Finnish Wartime Photograph Archive, and archives of the newspaper Keskisuomalainen. All photographs used were in the public domain, with most being taken by unknown photographers. The final game was published by the Museum of Central Finland.

\section{Data and analysis}

The data collected for this study included the games and their accompanying news stories and other written documents, project documentation from different project stages (e.g., project plans, game design documents, progress reports, reports of working hours by each individual participant, students' self- and team-level assessments and student feedback concerning the course) and observations of teachers throughout the project (cf. Frank \& Barzilai, 2004). Participation in the research was voluntary for the students, but all students decided to participate and signed consent forms at the beginning of the courses.

The data analysis followed the overall outline of qualitative content analysis, where the aim is to identify patterns and themes in the data to draw meaningful interpretations (Roller \& Lavrakas, 2015). Students' self- and team-level assessments and feedback were first anonymised and then analysed by categorising them based on their content. While parts of the initial analysis were carried out individually, the final key findings were the product of group discussions among the authors.

\section{Findings}

\section{Meeting the challenges of project work}

The analysis revealed that one of the most significant learning outcomes of the two courses was related to the importance of communication in teamwork. Working on the project revealed to the students the significance of constant communication within the team, with some students emphasising the benefits of regularly working together in the same physical space. Another aspect of communication was present in how the students described learning the importance of expressing their own ideas clearly to the rest of the team, specifically in a multidisciplinary context.

For some students, this was the first time they had participated in a group project where the group had an appointed leader or project manager. The significance of a team 
leader to the success of the project was one of the learning outcomes of the course, emphasised by several students. The role assignments in general helped the teams to ensure that key tasks were not left unattended. In the early stages of the project, the clear roles also made the lack of a specific skill set more visible. For example, a team that was missing a graphics or sound designer had to somehow react to this reality, either by attempting to outsource certain aspects of the development (e.g., asking for help from fellow students), finding creative solutions to the problem using the skills they already had (e.g., using and editing existing photographs) or toning down expectations concerning the final product.

Self-management and time management were other project management skills that were clearly visible in the analysis as significant learning outcomes. First, the amount of time required to design and develop a full-blown newsgame was easy to underestimate. There were several factors in the process that were difficult to anticipate. For example, some students had to learn new technological skills, and several teams encountered unpredictable setbacks due to challenges in collecting the right kind of data or reaching informants. This led to what is known in game development as a 'crunch' - a last-minute push where some key members of the team end up working overtime to the point of exhaustion (Peticca-Harris et al., 2015). For example, in the final presentation meeting, one coder noted that the last 2 weeks had seen him coding for at least 100 hours on top of all his other school work, while another commented that 'I would not want to show this code to anyone' (translated by the authors). Despite such difficulties, some participants expressed surprise at how far they were able to proceed during the course.

According to our findings, managing time use needs to be emphasised, especially when team members come from different academic backgrounds. For example, in our pilot courses, the ICT students were clearly more used to marking down their working hours. They had been trained to do so in their earlier studies and were thus able to discern their tasks and the time it would take to do them better than the journalism students. It is also possible that the organic and continuous work that the journalism students did when, for example, searching for data (e.g., calling experts, sending out emails to officials and going through the data to see if it was usable) was difficult to estimate beforehand. Many of the teams also suffered from poor time management in general, for example not agreeing early enough on mutual meeting times.

\section{Designing and developing newsgames}

According to our findings, the key challenge related to the design and development of newsgames was coming to terms with the concept of newsgames in the first place. Discussions on what newsgames are, could be and indeed should be were typical throughout the process.

The relationship between news and games, especially in connection with questions of truthfulness and realism versus the use of ludic affordances to their fullest, was an issue that all the teams returned to at times. In general, the participants expressed difficulties in finding a strong journalistic point of view that was able to fit well with a playful approach. On a parallel note, the participants stated that while it was often clear what the coders needed to do next, planning the work of the journalists seemed much more difficult. 
At the end of the course, we asked the participants about their perceptions of newsgames as a form of journalistic narration. In their responses, they expectedly pointed out how newsgames can make journalistic content more interesting and comprehensible. The students were somewhat critical of the suitability of games for journalistic narration, referring to both the nature of games as a medium and the economic and time demands of their development. Based on their responses to a question in the second self-evaluation, the participants reached an understanding of newsgames as a method for elucidating and illustrating difficult topics as well as making them more interesting for different audiences, even those not typically interested in journalism.

The participants also encountered challenges related to game development as a joint creative process. This became apparent, for example, when one team member's proposal was selected for further development over that of others. The disappointment in such cases could sometimes resurface much later in the game development process, manifesting, for example, as difficulties in finding motivation to work on an idea that was not only not your own, but also something you did not want to go forward in the first place.

At times, it was also challenging to take other stakeholders' viewpoints into account. For example, both the teachers and the representatives of the newspaper company ended up affecting the final products, sometimes in ways that were not in line with the team members' visions. This effect was especially clear during the second pilot course. During this course, all three newsgames ended up following a similar logic and form of relatively straightforward multiple-choice games with some random elements in the story structure and illustrated with static photographs. Judging from the way that the ideas and playtest sessions developed, it is likely that the feedback from the newspaper company had a significant influence on this outcome. On the other hand, in many cases, it was precisely this kind of feedback from the outside that helped improve the quality of the game. For example, in the case of The Situation Center, collaboration with the local police not only provided information, but also motivated the participants by offering real-life contact and feedback.

Finally, one of the key challenges as well as learning points related to designing and developing newsgames was balancing the plans with the available resources. Overall, the students' original plans were too ambitious. Each team had to go through several iterations where they had to drop certain features. This was done not only for practical reasons (e.g., time limitations), but also for playability reasons. While each student team did end up with a working prototype of a game, the result was never quite as polished as the original plan had promised. For example, at the beginning of the course, the participants worried about whether the collaborating newspaper would pay them for the end product. However, as the project was nearing its end, the teachers were more worried about whether the students could come up with a newsgame that is technically complete enough to be published in the first place.

In summary, our findings highlight the importance of learning about team dynamics and team leadership communication as well as the challenges and benefits of working in a team with diverse expertise. Students needed to learn numerous new skills both related to content creation as well as to work in a team, such as learning to better self-manage their use of time. The findings also highlight the tension between the journalistic frame of creating news stories and the way games and play are seen. Negotiating this tension was a key feature in practically every project during the two pilot courses. 


\section{Conclusions}

Overall, the two pilot courses can be considered a success. In the end, all but one newsgame were sold to Keskisuomalainen and published on its website. Moreover, the one game, Before, everything was..., focusing on the history of Finland, received an award from Statistics Finland, the national statistical institution (Jyväskylän yliopisto, 2017).

Our study highlights how multidisciplinary and project-based cooperation may benefit journalism education. The starting point for these types of courses does not lie in learning about or practicing established conventions, but rather in supporting participants in trying out flexible, emergent and creative ways of cooperation. Put short, courses such as those analysed here relate to the innovator mode of journalism education (Deuze, 2006).

The pilot courses succeeded in illustrating to the participants how challenging it is to work collaboratively in a multidisciplinary project team, as well as how much it takes to combine the journalistic process with the process of game design. The journalistic process often comes down to making sense of a complex and chaotic world, finding ways to present this understanding to diverse audiences. The process of designing games and simulations can be similar, but the level of simplification necessary for short, easy-topick-up online games is even more drastic than when writing a journalistic piece. The experience of multidisciplinary teamwork in developing newsgames can also lower the threshold for journalism students to engage in other new forms of technology-enhanced journalism, such as data journalism or machine learning, in their future careers.

While some studies have highlighted the challenges related to problem-based learning, including students skipping goal setting and strategy planning and often being unable to truly reflect on their progress (Oliver \& Omari, 2001: 46), the findings from our pilot courses illustrate how issues such as these may be circumvented through careful design and support from the teaching staff.

The pilot courses succeeded in highlighting several issues with relevance for the working life. The observation data and student feedback showed examples of students adapting to the often unanticipated twists and turns of the process of designing and implementing a newsgame, taking part in the necessary negotiations concerning team member roles and expectations and learning to cope with issues related to selfmanagement and time management. We were also able to see that working together with team members who represented a different academic background forced students to think about their own roles and what they could provide to the team. In this sense, our findings are in line with Heikkinen and Isomöttönen's (2015) claim that multidisciplinary teamwork can aid students in identifying their expertise and developing their professional identity. On a related note, we witnessed several instances where the participants ended up teaching one another. This applied to technological know-how as well as project-management and journalistic thinking. It is interesting to note that this also held true for the faculty, with co-teaching providing opportunities for peer support as well as professional development in pedagogical skills and knowledge (Bacharach et al., 2008: 13-15).

We propose that teachers working in the field of journalism should adopt an openended, project-based approach when dealing with new phenomena. Here, learning happens at all possible levels: between teachers, among teachers and students and in collaboration with outside partners. Courses such as the one presented in this paper illustrate how project-based cooperation may lead to the creation of new insights into 
emerging phenomena, thus taking higher education in journalism beyond the established content and conventions.

\section{Funding}

This study was supported by the Academy of Finland project 'Centre of Excellence in Game Culture Studies’ Grant no. [CoE-GameCult, 312397].

\section{Notes}

1. https://www.finna.fi/Record/hkm.HKMS000005:00000511

2. https://finna.fi/Record/musketti.M012:HK19731119:5222

\section{References}

Aitamurto, T., Sirkkunen, E. \& Lehtonen, P. (2011). Trends in Data Journalism. NextMedia D.3.2.1.2.B: Helsinki.

Appelgren, E. \& Nygren, G. (2014). Data journalism in Sweden. Introducing new methods and genres of journalism into "old" organizations. Digital Journalism, 2(3): 394-405. doi: https://doi.org/10.1080/2 1670811.2014 .884344

Aronson-Rath, R., Owen, T., Pitt, F. \& Milward, J. (2015). Virtual reality journalism. Tow Center for Digital Journalism at Columbia University. Retrieved from https://towcenter.gitbooks.io/virtual-reality-journalism/content/ [accessed 2019, May 13].

Ausserhofer, J., Gutounig, R., Oppermann, M., Matiasek, S. \& Goldgruber, E. (2017). The datafication of data journalism scholarship: Focal points, methods, and research propositions for the investigation of data-intensive network. Journalism, 1-24. doi: https://doi.org/10.1177/1464884917700667

Bacharach, N., Heck, T. W. \& Dahlberg, K. (2008). Co-teaching in higher education. Journal of College Teaching and Learning, 5(3): 9-16.

Berret, C. \& Phillips, C. (2016). Teaching data and computational journalism. Columbia Journalism School: New York. Retrieved from https://journalism.columbia.edu/system/files/content/teaching_data_and_computational journalism.pdf [accessed 2019, May 13].

Bogost, I., Ferrari, S. \& Schweizer, B. (2010). Newsgames: Journalism at play. Cambridge: MIT Press.

Coddington, M. (2015). Clarifying journalism's quantitative turn: A typology for evaluating data journalism, computational journalism, and computer-assisted reporting. Digital Journalism, 3(3): 331-348.

Conway, S. (2014). Zombification? Gamification, motivation, and the user. Journal of Gaming and Virtual Worlds, 6(2): 129-141.

De la Peña, N., Weil, P., Llobera, J., Giannopoulos, E., Pomés, A., Spanlang, B., Friedman, D., Sanchez-Vives, M. V. \& Slater, M. (2010). Immersive journalism: Immersive virtual reality for the first-person experience of news. Presence, 19(4): 291-301.

Deuze, M. (2006). Global journalism education: A conceptual approach. Journalism Studies, 7(1): 19-34.

Eliot, G. (1996). Brief history of crossword puzzles. American crossword puzzle tournament. Retrieved from http://www.crosswordtournament.com/more/wynne.html [accessed 2019, May 13].

Ellis, D. (2009). "Problems may cut right across the borders": why we cannot do without interdisciplinarity. In B. Chandramohan \& S. Follows (eds.) Interdisciplinary learning and teaching in higher education: Theory and practice (pp. 3-17). Routledge: New York.

Foxman, M. (2014). Play the news: Fun and games in digital journalism. Columbia Journalism School. Tow Center. Retrieved from https://academiccommons.columbia.edu/doi/10.7916/D8J67V59 [accessed 2019, May 13].

Frank, M. \& Barzilai A. (2004). Integrating alternative assessment in a project-based learning course for preservice science and technology teachers. Assessment \& Evaluation in Higher Education, 29(1): 41. doi: https://doi.org/10.1080/0260293042000160401

\section{Acknowledgements}

We would like to thank all the students who took part in the two pilot courses, as well as the contact people at the newspaper Keskisuomalainen. Without your participation and interest in the project, this article would not have been written. 
A Pilot Study on Developing Newsgames in Collaboration between Journalism and Computer Science Students

Fuchs, M. (2014). Gamification as twenty-first-century ideology. Journal of Gaming and Virtual Worlds, 6(2): $143-157$.

Goldberg, D., Corcoran, M. \& Picard, R. (2013). Remotely piloted aircraft systems \& journalism: Opportunities and challenges of drones in news gathering. Oxford: Reuters Institute for the Study of Journalism.

Gynnild, A. \& Uskali, T. (2018). Responsible drone journalism. London: Routledge.

Heikkinen, J. \& Isomöttönen, V. (2015). Learning mechanisms in multidisciplinary teamwork with real customers and open-ended problems. European Journal of Engineering Education, 40(6): 653-670. doi: https://doi.org/10.1080/03043797.2014.1001818

Jyväskylän yliopisto. (2017). Opiskelijoiden peli voitti tilastojen havainnollistamisen kilpailun [Students' game won the competition of how to visualise statistics]. Retrieved from https:/www.jyu.fi/ajankohtaista/ arkisto/2017/11/tiedote-2017-11-24-09-23-43-363275 [accessed 2019, May 13].

Helle, L., Tynjälä, P. \& Olkinuora, E. (2006). Project-based learning in post-secondary education: Theory, practice and rubber sling shots. Higher Education: The International Journal of Higher Education and Educational Planning, 51(2): 287-314.

Hesmondhalgh, D. (2019). The Cultural Industries. (4 ${ }^{\text {th }}$ ed.). Sage: London.

Lassila-Merisalo, M. \& Uskali, T. (2011). How to educate innovation journalists? Experiences of innovation journalism education in Finland 2004-2010. Mass Communication and Journalism Educator, 66(1): $25-38$.

Martin, J. D. (2017). A census of statistics requirements at U.S. journalism programs and a model for a "statistics for journalism" course. Journalism and Mass Communication Educator, 72(4): 461-479.

Oliver, R. \& Omari, A. (2001). Student responses to collaborating and learning in a web-based environment. Journal of Computer Assisted Learning, 17: 34-47. doi: https://doi.org/10.1111/j.13652729.2001.00157.x

Peticca-Harris, A., Weststar, J. \& McKenna, S. (2015). The perils of project-based work: Attempting resistance to extreme work practices in video game development. Organization, 22(4): 570-587. doi: https:// doi.org/10.1177/1350508415572509

Plewe, C. \& Fürsich, E. (2017). Are newsgames better journalism? Empathy, information and representation in games on refugees and migrants. Journalism Studies, 18: 1-18. doi: https://doi.org/10.1080/14616 70X.2017.1351884

Redshaw, C. H. \& Frampton, I. (2014). Optimising inter-disciplinary problem-based learning in postgraduate environmental and science education: Recommendations from a case study. International Journal of Environmental and Science Education 9: 97-110.

Rejeski, D., Chaplin, H. \& Olson, R. (2015). Addressing complexity with playable models. The Wilson Center. Retrieved from https://www.wilsoncenter.org/sites/default/files/playable_model.pdf [accessed 2019, September 30].

Roller, M. R. \& Lavrakas, P. J. (2015). Applied qualitative research design: A total quality framework approach. New York: The Guilford Press.

Savin-Baden, M. \& Major, C. (2004). Foundations of problem-based learning. Maidenhead: McGraw-Hill Education.

Servaes, J. (2009). Back into the future? Re-inventing journalism education in the age of globalization. In G. Terzis (ed.) European journalism education (pp. 521-541). Bristol: Intellect.

Sicart, M. (2008). Newsgames: Theory and design. In Stevens, S.M. \& Saldamarco, S. (eds.) ICEC 2008, LNCS 5309 (pp. 27-33) Springer: Berlin.

Siitonen, M. \& Launonen, S. (2014). Viihteen ja vakavuuden rajoilla - käyttäjien kokemuksia uutispeleistä [On the border between play and seriousness - users' experiences of newsgames]. Pelitutkimuksen vuosikirja 2014, 41-50.

Stefani, L.A.J. (2009). Assessment in interdisciplinary and interprofessional programs. In B. Chandramohan, \& S. Follows (eds.). Interdisciplinary learning and teaching in higher education: Theory and practice. London: Routledge.

Thussu, D. K. (2007). News as entertainment: The rise of global infotainment. Thousand Oaks, CA: Sage.

Van Buskirk, E. (2010). Will Columbia-trained, code-savvy journalists bridge the media/tech divide? Wired, April 7. Retrieved from http://www.wired.com/2010/04/will-columbia-trained-code-savvy-journalistsbridge-the-mediatech-divide/ [accessed 2019, May 13].

Copyright: (C) 2019 The Author(s) and Nordicom. This is an open-access article distributed under the terms of the Creative Commons Attribution 4.0 International License (CC BY-NC-ND 4.0). 